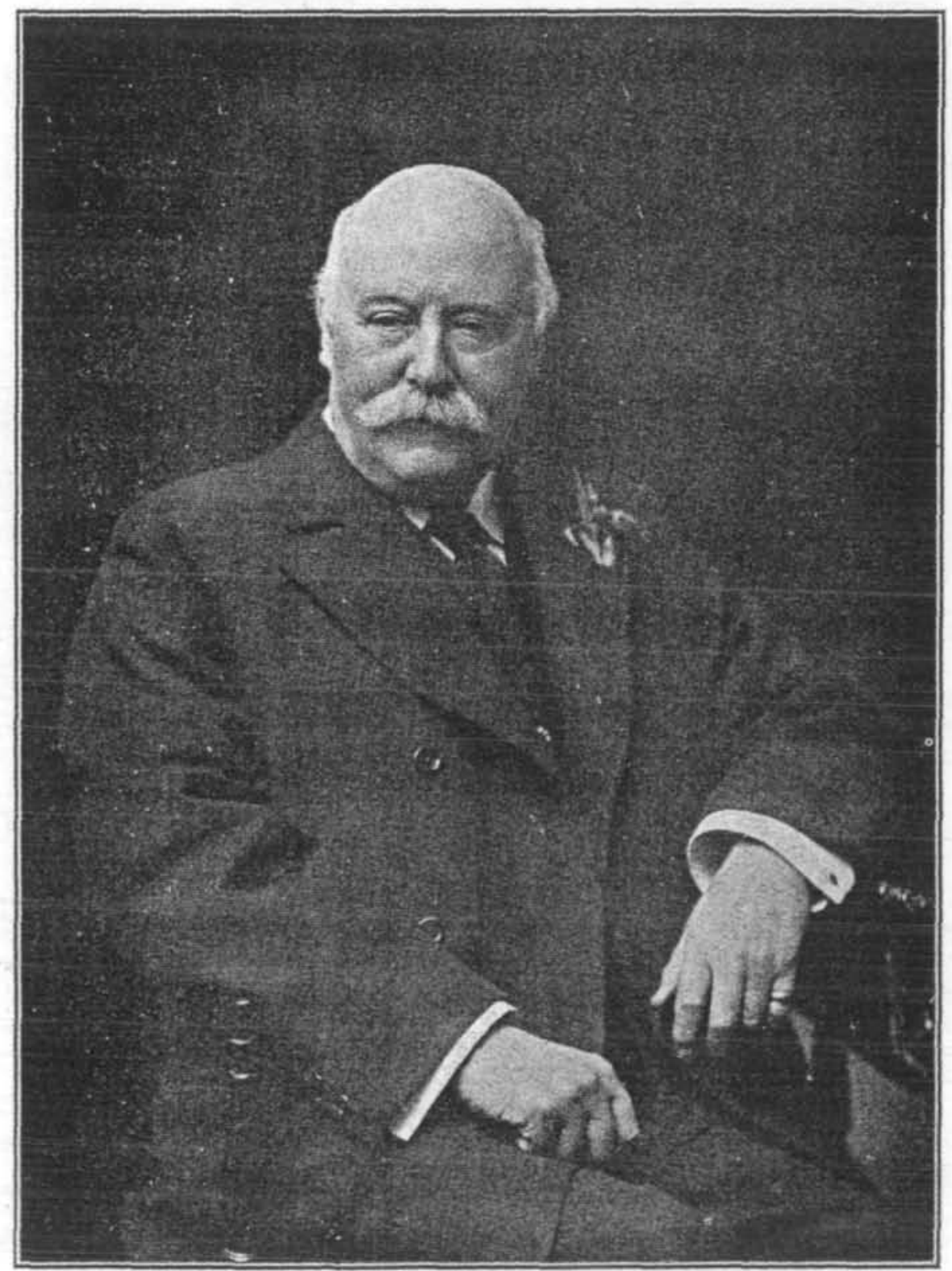

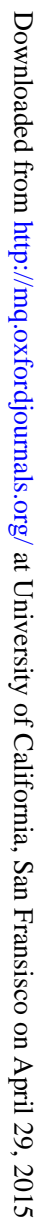

Sir Hubert Parry 


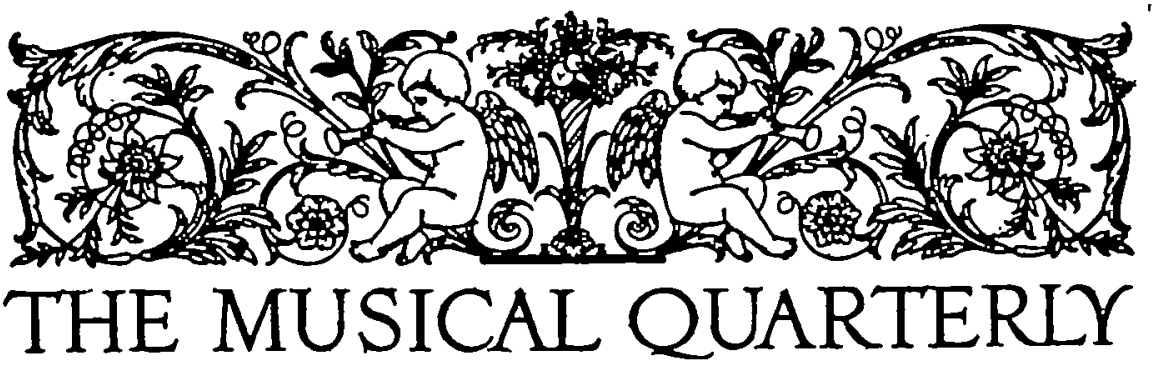

VOL V

JULY, 1919

No. 3

\section{HUBERT PARRY}

\section{By J. A. FULLER-MAITLAND}

7 HE great man whose ashes were placed in St. Paul's Cathedral on Oct. 16, 1918, was so typical an Englishman that the sense of public bereavement shown on that occasion was all the more wonderful since the English reluctance to believe in any important musical achievement by a countryman has not yet been overcome, although the war has already done much to encourage a more reasonable attitude towards national music.

In birth, breeding, education, and musical training, Charles Hubert Hastings Parry was an example of the best that England can produce. The surroundings of a "county family" in the depth of the English country are so often sneered at by 'superior' people that it may be worth while to point out that the intellectual squalor and general indifference to matters of art, so much insisted on by popular novelists, is not always true to nature. The composer's father, Thomas Gambier Parry, owner of Highnam Court, Gloucester, was not merely an eminent collector of works of early Italian art at a date when very few people had the taste to choose what was best, but was himself a painter and designer of no small skill, and the inventor of a process of "Spirit fresco" which he used in his private chapel at Highnam as well as in Ely Cathedral. In the other arts, as in literature, the home atmosphere was most congenial to the soul's growth. Born, Feb. 27, 1848, at Bournemouth, the future composer was at a preparatory school when he came under the musical influence of Samuel Sebastian Wesley, and by the time he entered Eton his musical powers were already active. The taking of the degree of Bachelor of Music by an Eton boy is not a usual event, and many of us would have 
given much to hear his exercise performed at the school, or to have been present when Parry sang the part of "Elijah" at a performance conducted by Sir J. F. Bridge.

It is to the lasting honour of the famous "Festival of the Three Choirs" that its committees are apt to recognize the claims of local composers; and it was when Parry was only twenty years of age that his "Intermezzo religioso" for strings was performed at the Gloucester Festival. After his Oxford career at Exeter College, where studies and sports occupied the first place in his activities, the career of a business man was tried for three years, but happily music was too strong, and by this time, he had a certain amount of musical training from Sterndale Bennett, G. A. Macfarren, and H. H. Pierson, with the last of whom he studied at Stuttgart, after that composer had expatriated himself and adopted a German way of spelling his English name. But these influences were very slight on Parry, compared with that of Edward Dannreuther, whose intimate friendship was of the greatest benefit to Parry through many years of residence in London. It was owing to Dannreuther that Parry could have the opportunity of hearing performances of numerous works of chamber music, and many amateurs must remember the studio in Orme Square (consecrated to music by the fact that Wagner read the libretto of Parrifal before the music was composed, to a party of admirers in that room in 1877) and the impression created by the strikingly new note in the compositions, the recollection of which is inseparably connected with the look of the walls streaming with moisture like some subaqueous cave resonant with strange harmony. Not that the sounds were always beautiful, for Parry must needs fight his way to free expression by slow degrees in these higher forms of composition; but the hearer felt that he was in the presence of something big that might be trusted to develop in unexpected directions. It seemed that a harsh fate waited upon the concerts, for the MSS. were generally taken home by the composer, and very often lost. The programmes remained for years as the only evidence that the works had ever existed, and when complaint was publicly made that they had disappeared, diligent search in the composer's house revealed that several were still in existence, so that they are now accessible, though it is almost certain that they have undergone revision since the first performance.

A private concert at the house of the Right Hon. A. J. Balfour introduced some of these and some other compositions (not now to be identified) to a larger circle of music-lovers than the 
audience at Dannreuther's house; in 1880 Dannreuther played a piano concerto at the Crystal Palace, and, more important still, the "Scenes from Shelley's Prometheus Unbound" were given at the Gloucester Festival in the autumn of that year. It was typical of the state of music in England at that date that this work should have been a failure almost unqualified. The critics, soaked in the Mendelssohn tradition, had hardly recovered from the upsetting effect of the Wagner Concerts at the Albert Hall in 1877, and saw Wagner's influence in places where it did not exist.

It is difficult in the present day to imagine what it was in this work that so bitterly offended them; and it has been suggested that the presence of two distinguished amateurs among the soloists may have been one of the hidden causes. It is more likely that the comparative $y$ meagre conditions under which secular cantatas were presented at these cathedral festivals (in a small concertroom, before a tired audience, and with rather maimed rites generally) had a good deal to do with the failure. It is possible to speak with the more confidence about the work itself, since it was revived by the Bach Choir on two occasions; yet even so, a reading of the score makes it difficult to believe that it has not been hailed as one of the first and greatest glories of the renaissance of English music. The solemn opening, pregnant with tragedy, leads to a long soliloquy in which the perfect musical counterpart is found for the poet's words. One cannot guess from which, if any, of his teachers, Parry acquired that wonderful skill in accentuation, or as it sometimes called, "declamation," in which he is unrivalled among his countrymen. Already, in these early days, every syllable seems to bear its "just note and accent" (to quote Milton on Henry Lawes) and the vocal inflections throughout are such as are suggested by the poet's phrases. The solo of Earth, "I felt thy torture, son," has many of the most characteristic features of Parry's lyrical style; dignified, original, expressive, it yet often fails in immediate appeal, perhaps from these very qualities, since the average hearer expects a kind of emotion that 'slops over,' and is disappointed .when this music does not slop over. The tenor solo in the second division of the work, "Pour forth heaven's wine, Idæan Ganymede" is one of those irresistible and spontaneous melodies which Parry not seldom gave us. Many of the song-writers of modern times, whose methods are of the purest and most artistic, produce a bar or two of exquisitely right expression, which seems to have come forth in one gush of feeling; but very often the continuation of the strain is of lamentably uninspired quality. This splendidly 
vivid and free melody goes right on to its conclusion without faltering or flagging, and has the stamp of that eternal youthfulness which marks the opening song of the set published only about a week or two before the composer's death (English Lyrics, book X) as distinctly as it does the second of the Anacreon odes "Fill me, boy, as deep a draught," an achievement of the Eton days. There is in Prometheus more than a foreshadowing of that superb power of choral architecture, a vein which the master worked so successfully in later life. The stupendous choruses of Job, and of many of the later cantatas, owe something to Purcell, and the taste for such types of music - one of the healthiest signs in English music,was handed down through the choruses of Handel.

This vein was further worked in the work produced at Gloucester at the next festival, 1883, by which time the English critics had begun to come to their senses and to be conscious that a new note had been struck by a countryman of their own. Shirley's "The glories of our blood and state" carried on the succession of grand choruses, and four years after this came the crowning work in this kind, the immortal setting of Milton's Ode at a Solemn Music brought forward by the Bach Choir in London in 1887. "Blest Pair of Sirens" (the work is generally known by its opening words) is unsurpassed as a wedding of perfect music unto noble words; musically, its splendidly ordered design, leading us from climax to climax, is a model for the student, although the student who is cold-blooded enough to notice its structural beauty during its performance is not likely to profit by the study of this or of anything else. Of course, after this triumph, it was inevitable that every festival should provide a choral work by Parry as a chief attraction. It would be impossible in this place to make a complete catalogue of these festival works (some 20 in number), which, though for very different reasons, have been almost as seldom heard after their first production as the early chamber compositions given at Dannreuther's studio; the anxiety to get hold of a new cantata by Parry was so great that few of the festival authorities had the sense to see that a far greater work would have been done if they had given the public a chance of bettering their acquaintance with music already performed. Had they been wiser, the musical part of the nation would have been led to recognize, more fully than has been possible, the greatness of the composer, and he himself would have been able to experiment in new forms of beauty instead of wearing himself out in producing an annual cantata which might or might not contain some passage of the highest distinction. But these things are 
unalterable, and we must await the day of the rediscovery of these works, an event which is almost as inevitable as the rediscovery of Bach's church cantatas. It is more likely that these comparatively short compositions will be revived some day than that a new opportunity should occur of hearing the larger oratorios, Judith (1888), Job (1892) or King Saul (1894); for even before the war the conditions of music in England were so rapidly changing (for the worse or the better, who shall say?), that the old supremacy of oratorio over every other form of music had been virtually done away with, and as a consequence of such a dethronement, it is very probable that modern oratorio at least will be heard no more. In the later years of his life, Parry turned his choral skill to further account in a good many unaccompanied works, alike in the form of madrigals, part-songs, and motets.

If we must be content to leave the oratorios and many of the cantatas on the shelf for the present, it is pretty certain that the composer's songs will increase in general popularity, as all things are bound to do that are produced without reference to passing fashion or the demands of publishers. There are a fair number of songs belonging to the earliest period of Parry's career (before the ten series of "English Lyrics"), which are of extreme beauty and which are always sure of a welcome when singers are lucky enough to find them. "Why does azure deck the sky?" "More fond than cushat dove," and "A Contrast" are occasionally to be heard and are of exquisite quality. The publication of the successive series of "English Lyrics" removes the only valid excuse from singers who do not care to sing them that they are not accessible. Throughout all the books, the same wonderfully faithful following of the poetical accentuation is to be observed, and there are songs in every mood excepting only the lackadaisical and ultra-sentimental. The finest complete book is perhaps the ninth, to words by Mary Coleridge, in which "Armida's Garden" has an unusually exotic atmosphere, like "Through the Ivory Gate" of set 3, and "There" reaches the highest point of religious fervour. Delicate humour appears in "Why so pale and wan?" (set 3), "A Stray Nymph of Dian" (set 5), and "A Girl to her glass" (set 5); and a more boisterous fun in "When icicles hang by the wall" (set 2), "Of all the torments" (set 3 ), and "Love is a bable" (set 6). One of the most beautiful of all is "My heart is like a singing bird" from the tenth set, and one of the most charming the last of the same book, "One silent night of late," although the composer unfortunately chose an incorrect text of Herrick's poem about Love coming in to dry his wings and then shooting 
his host. It is not difficult to restore the proper text, but the work should be taken in hand at once, or the errors will be transmitted from one "book of words" to another, until the false reading be as commonly found as that irritating and almost universal blunder "But might I of Love's nectar sip" for "But might I of Jove's nectar sup" in "Drink to me only."

Humour was one of Parry's most precious gifts, and no one who has witnessed the performance of Aristophanes' Birds, the Clouds, or the Frogs, could fail to realize the fun that was part of the composer's nature. The first of these compositions of incidental music for University performances of Greek plays, contains, in the final march, one of Parry's most spontaneous inspirations, a piece that ought to supersede the Midsummer Night's Dream weddingmarch of Mendelssohn for ceremonial use.

Like other great song-writers, Parry was often supposed not to write easily for the voice; like them, he will be found innocent of the accusation if singers will only bring a little intelligence to the task of interpreting him.

At the present moment, it would seem that Parry's instrumental works are of less importance in the public esteem than his choral. As I have already said, he was obliged to fight every step of his way to complete freedom of expression in instrumental music; but in his treatment of form the instrumental works are of great importance. Certain early pianoforte pieces are now quite inaccessible, owing to curious conditions not unconnected with the English publishing trade; the finest, a delightful sonata"To Cora"-is still happily obtainable; the "Nineteen Variations" in $\mathrm{D}$ minor is sometimes to be heard, and is an example of a problem that was very attractive to Parry as one may see from his masterly article in Grove's Dictionary, on "Variations." How is a set of variations to be unified? is the short way of putting the question, and in these piano variations there is one solution, while in the orchestral work by which the composer is perhaps best known, his "Characteristic Variations in E minor" another answer seems preferred. Both are very fine specimens of the form, and in other conditions either or both might have led on to a new development of the type. As a matter of course, it was not possible for Parry to do very much in the way of striking out new paths for himself or anybody else after his appointment to succeed Sir George Grove as Director of the Royal College of Music, a post he held with the utmost distinction from 1894 until his death. The early chamber compositions seem as if an attempt was being made to combine the profundity of Bach with the elaboration of 


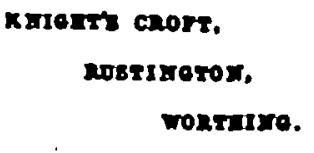

Ature $24 \cdot 1916$

Iny dear old wortity

Your letter was a freat foy torme. I confen' ' care a cood deal for $t$ finmon

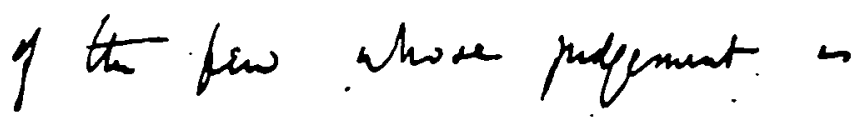
wonth haunif ; the we nut ment leam tho wisthent. As one By courtesy of Mr. J. A. Fuller-Maitland 
fit h on an gears one warden solutions

II her not mostly ben sure waste of effort - and then if a squplative greeting tel yours comes one feels more

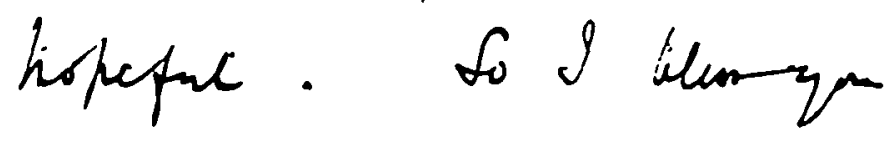
and feel helped.

I has ration tor ty a done 
If womes and ouch the eapuncines lost tem and felt fainly kenque cut at the cue of $t$, is are wout trichinam gine wech, where froen is i hossming for a fow monthe ; and then $f$ cutainly had ith change f.acenpation for inotiff my time was hathe of with andequnut fo difuray of the temite urukey of then 


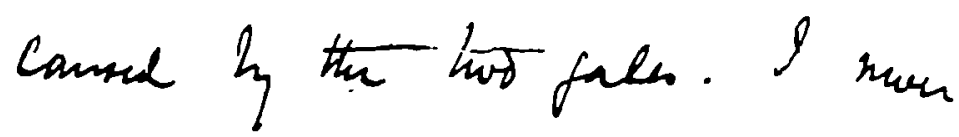

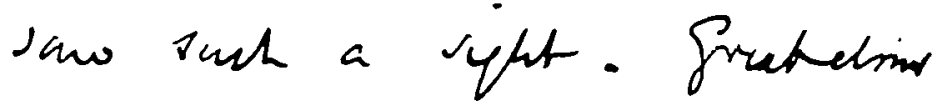
living a tof of andin a whe averne destinge and

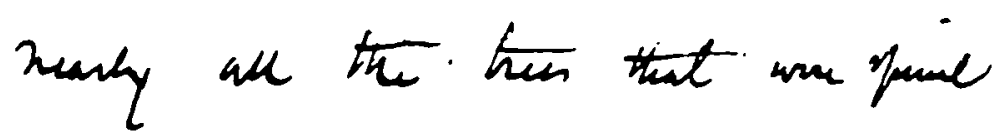
feateres a the Candscape laid Inj: 9 wonder hav yo foned in the bluguere and suthen its an cald wh ype a it in here.

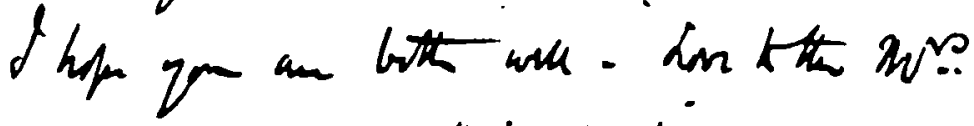
ys affect dd fine Etimuth Paris 
classical forms as developed after Beethoven. Bach had always the strongest possible influence on Parry, and the fine "Grosses Duo" for two pianofortes is as heartfelt a tribute to the greatest master of all as are the "Choral Preludes" for organ published a few years before Parry's death. The "Partita" for violin and pianoforte and the pianoforte suite, "Hands Across the Centuries" (the latter published quite recently) show how fully he had mastered the conventions of the 18th century, and how skilfully he could apply them to modern conditions. In the question of writing for the orchestra, from the overture "Guillem de Cabestanh" (1879) onwards to his three symphonies, Parry declared himself more interested in form than in colour; as a natural consequence the purveyors of music for our present-day orchestral concerts do not trouble themselves much about his music, which therefore has to repose on the shelf with the orchestral works of Schumann and Brahms, and how many more?

One important branch of music is absent from Parry's list of compositions as it is from that of Brahms. One often wonders what an opera by Brahms would have been like, and the guess is less profitable than usual since Brahms wrote so very little that was at all theatrical in style. Parry's music to the Greek comedies above mentioned, and to Agamemnon (Cambridge, 1800), to say nothing of his fine incidental music to two plays produced in London, leads one to suppose that his single experiment in opera, on the subject of the Morte $d^{\prime}$ 'Arthur might reveal strong dramatic powers; whether it was ever finished, or whether the scoring is complete, I do not know.

It remains to speak of Parry's literary achievements, which are of exceptional quality as well as of unusually large extent for a creative musician. Studies of Great Composers (1886), has great value as something more than a text-book; The Art of $M u$ sic (1893), was enlarged and republished in 1896 as The Eoolution of the Art of Music; it is a fine epitome of musical history, treated with much individuality and literary skill. The third volume of the Oxford History of Music, under the title of The Seventeenth Con'tury, appeared in 1902, and Johann Sebastian Bach, a particularly valuable critical study of the English composer's favourite master, appeared in 1909. In 1911, his last and most valuable literary work, Style in Musical Art, appeared and quickly won recognition as a book of rare authority and practical as well as asthetic value. A book of greater extent than any of these,-not dealing with music-occupied his scanty leisure in his later years, and seems to have been virtually finished before his death. His articles in 
Grove's Dictionary, and many beautiful poetical passages in the cantatas, must not be forgotten.

It was perhaps not an unqualified benefit to music that Parry was appointed to the directorship of the Royal College, for the post naturally demands such administrative power that no occupant of it could possibly protect sufficient leisure to conceive or carry out any work of art of the larger kinds. Great as was Parry's influence on the students under his care, yet it is impossible not to regret those compositions which would in all probability have been given to the world if his time had not been more than fully taken up with the affairs of the college. He lacked the power of deputing his work to others, and would always answer a letter himself, sooner than employ a secretary. This was partly the result of his fervid, sanguine temperament, a possession which made him less than the ideal conductor. In any new work of his own, which, according to custom, he was expected to conduct on its first appearance, he would almost certainly be apt to hurry the pace, and to obscure the general design of the work by the agitation that spread from himself to his performers. On the other hand, his wonderful frankness and geniality of manner made it the most grateful task in the world to do one's best for his sake, for every executant felt in close personal relation with the composer, and it has been said that he perfectly fulfilled the two ideas conveyed by the German and English meaning, respectively, of the word genial. Genius and geniality were indeed the two qualities that first struck those who came into contact with Parry. Whether consciously or not, this frankness of manner was occasionally used as a kind of protective covering. The word "mask" conveys an idea of disguise, and nothing was more foreign to Parry's nature than dissimulation of any kind; but yet the cheery manner must often have been adopted when anxieties or difficulties of any kind were present behind it. Gibbon says of Mahomet, "The frankness of his manner concealed the artifice of his views; and the habit of courtesy was imputed to personal friendship or universal benevolence." With the single exception of the word "artifice," this sentence might stand as a portrait of Parry. His ardent nature led him to embrace, in early life, political views of the most advanced and idealistic kind, which were somewhat modified in later years. In these later years, too, he turned his attention more than before to themes of a religious kind; the series of motets for unaccompanied chorus, the finest of which, 'There is an old belief,' was sung at his funeral, are of no less importance than the three series of organ preludes 


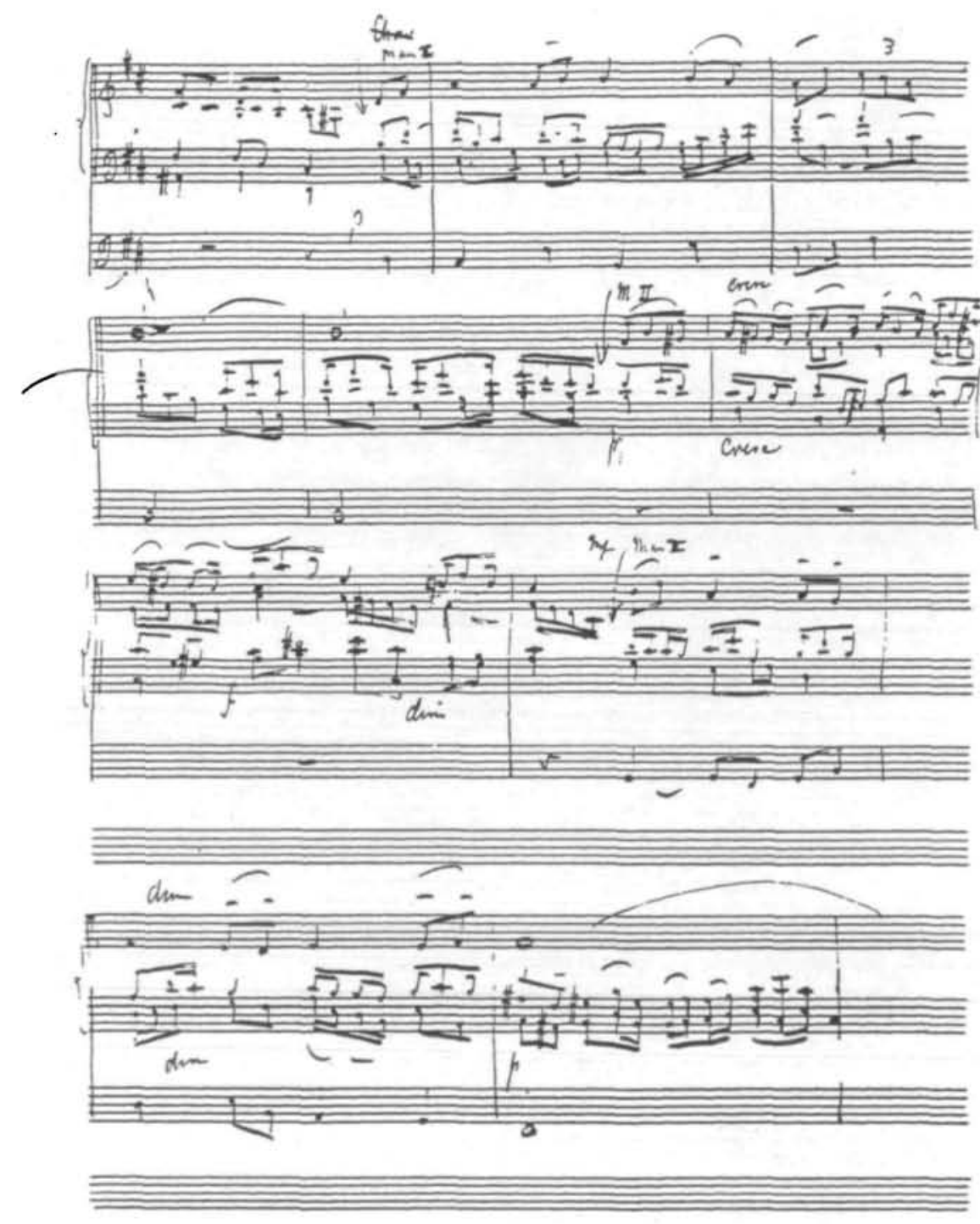




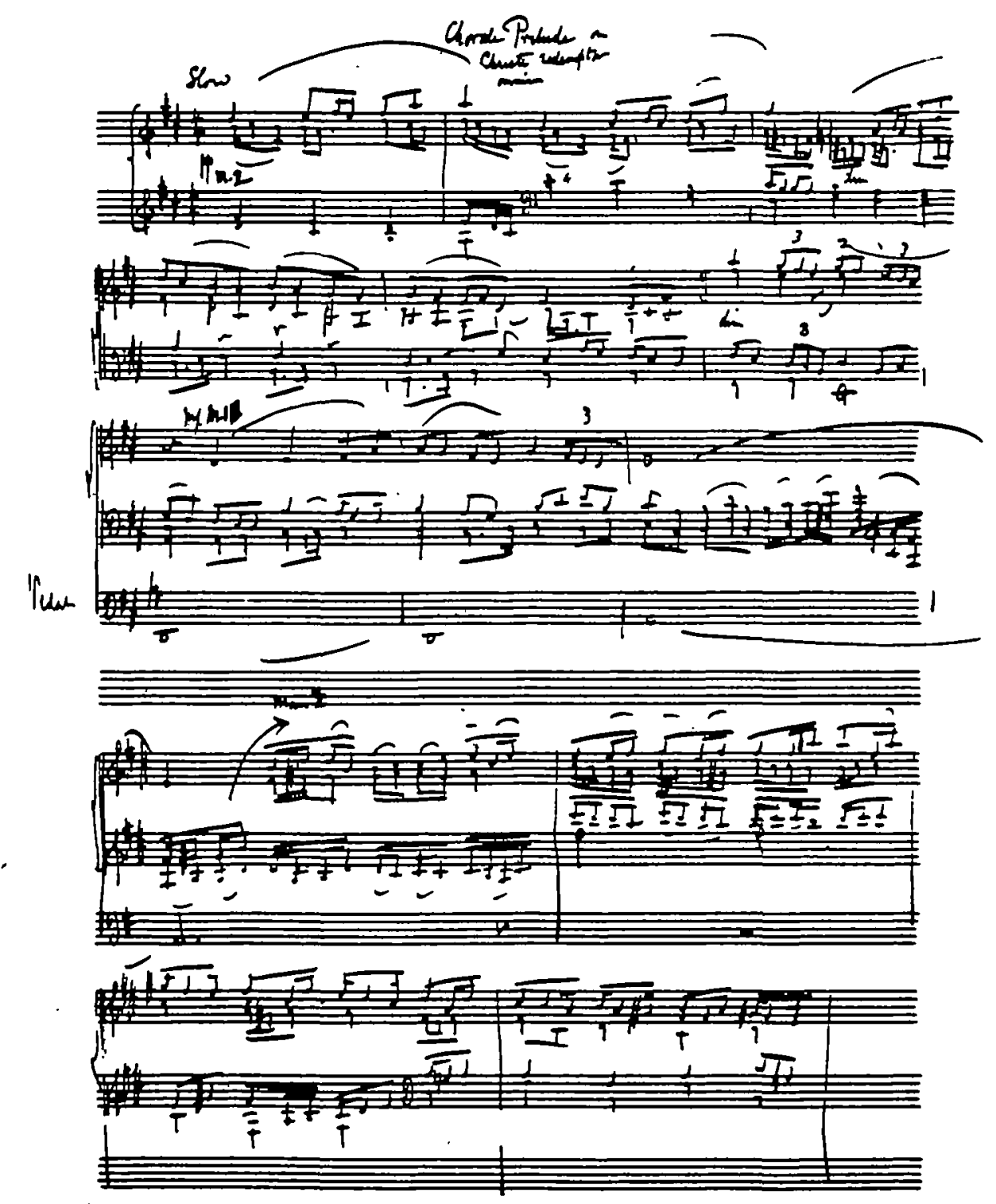

By courtesy of Lady Maud Parry 

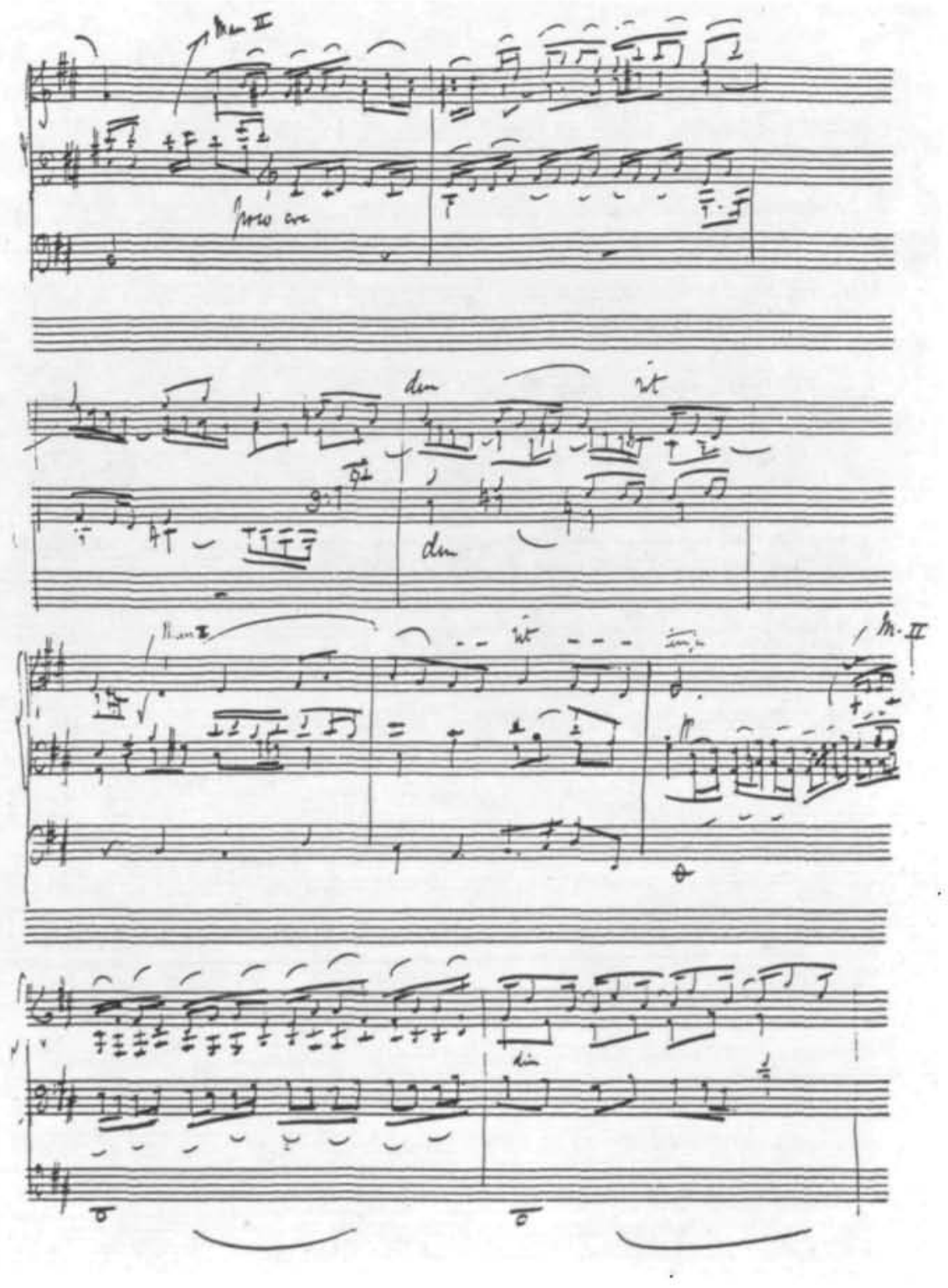


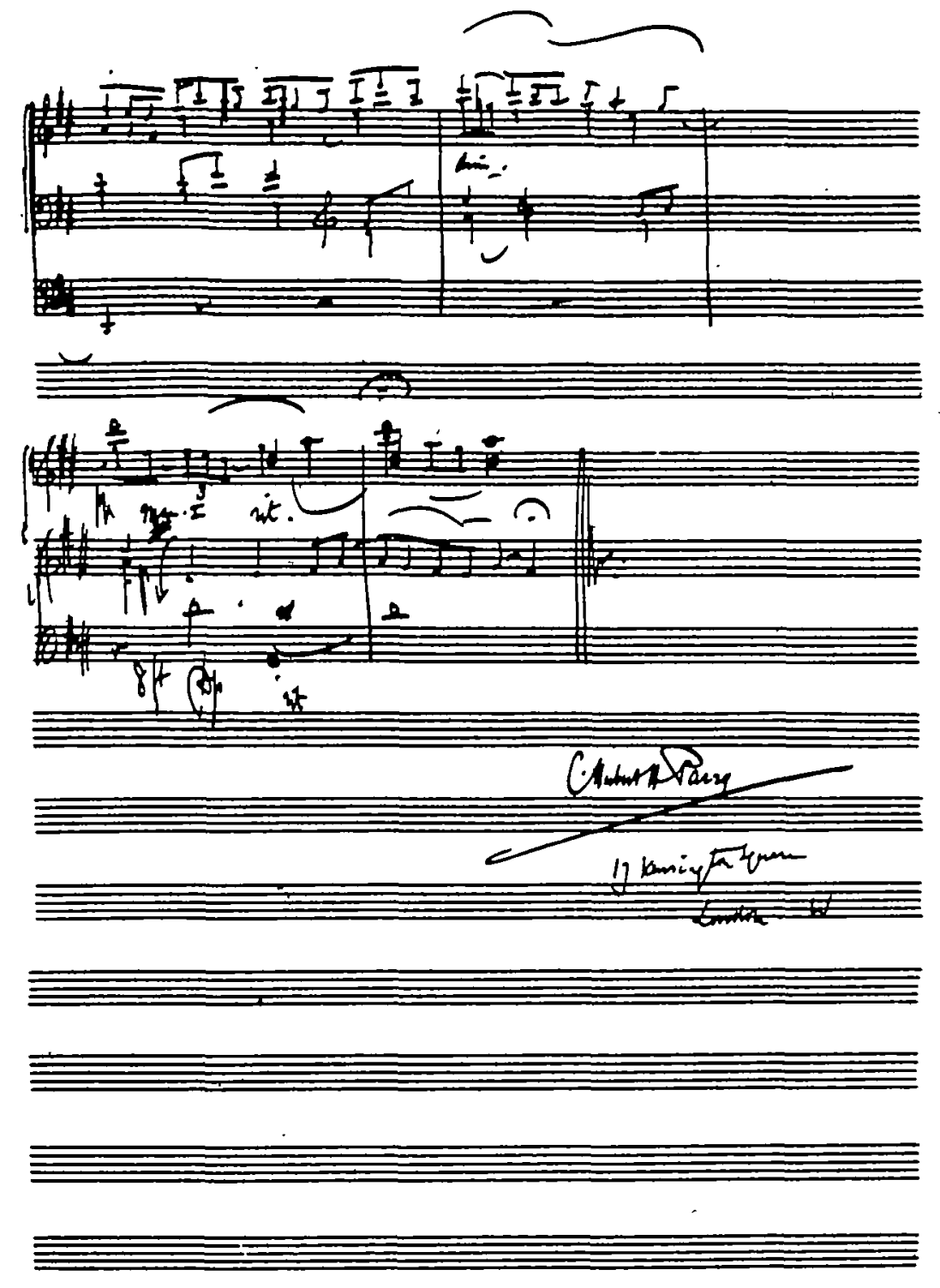


or fantasias on well-known hymn-tunes. The impossibility of carrying out schemes of a larger kind may have had something to do with Parry's choice of these comparatively short forms, but whatever the reason, the world is a good deal richer for the things themselves, which must rank with the best of his compositions. In some of the larger cantatas and odes, there are traces of fatigue in the constant employment of sequences, an expedient which at one time seemed likely to become a mannerism; but in these later works, there is nothing of the kind. The "choral preludes" are in the vein of Bach, that vein which Parry had worked so often and so successfully before; but the treatment, with its full recognition of the resources of the modern organ, is as independent of Bach as the tunes are of the German chorals. One, on "Christe redemptor omnium," has been reproduced in facsimile as an illustration of this article, by kind permission of Lady Maude Parry the composer's executor. The second of a set of three "choral fantasias," on a hymn-tune of the 18th century, reaches a depth of elegiac poignancy that the composer has not touched elsewhere; and if a note of abandoned grief had been allowed to be heard in the memorial service at St. Paul's, this would have been its fittest expression. But it was wise and appropriate, no doubt, that a life of such victorious accomplishment as his should be crowned with an almost triumphal ceremony. 